\title{
ASSESSMENT OF UTILIZATION POSSIBILITIES \\ OF HEAT CONDUCTED BY WASTE GASES EXHAUST PIPE OF SB 1.5 DRUM DRIER FOR DRYING WOOD CHIPS
}

\author{
Mariusz Surma $^{\mathrm{a}^{*}}$, Zbigniew Zdrojewski ${ }^{\mathrm{a}}$, Stanisław Peroń ${ }^{\mathrm{b}}$, Klaudiusz Jałoszyński ${ }^{\mathrm{a}}$, \\ Bogdan Stępień ${ }^{\mathrm{a}}$ \\ ${ }^{\text {a }}$ Institute of Agricultural Engineering, University of Life Sciences in Wroclaw \\ ${ }^{\mathrm{b}}$ State Higher Vocational School in Sulechow \\ *Corresponding author: e-mail: mariusz.surma@up.wroc.pl
}

\begin{tabular}{|c|c|}
\hline ARTICLE INFO & ABSTRACT \\
\hline $\begin{array}{l}\text { Article history: } \\
\text { Received: September } 2015 \\
\text { Received in the revised form: } \\
\text { October } 2015 \\
\text { Accepted: November } 2015\end{array}$ & $\begin{array}{l}\text { Based on the exploitation research, the authors evaluated the possibili- } \\
\text { ties of using the heat conducted through the side surface of the waste } \\
\text { gases exhaust pipe of SB } 1.5 \text { drum drier for drying wood chips. Ac- } \\
\text { cording to the estimated calculations within one hour approximately } \\
173 \text { thousand of kJ of heat may be obtained from the external surface }\end{array}$ \\
\hline $\begin{array}{l}\text { Key words: } \\
\text { exhaust heat, } \\
\text { drum drier, } \\
\text { wood chips, } \\
\text { drying }\end{array}$ & $\begin{array}{l}\text { of approximately } 78^{\circ} \mathrm{C} \text { which constitutes an equivalent of approx- } \\
\text { imately } 4 \text { kilo of heating oil. In case the above mentioned heat source } \\
\text { for drying wood chips in SPA } 20 \text { silo with a volume of } 6800 \text { kilo } \\
\text { within } 50 \% \text { to } 20 \% \text { humidity is used, one may expect that the drying } \\
\text { time will be approximately } 100 \text { hours. }\end{array}$ \\
\hline
\end{tabular}

\section{Introduction}

Driers used in agriculture, agri-food industry and chemical industry include hightemperature drum driers. Schematic representation of SB 1.5 drum drier used, inter alia, for drying fodder, by-products of the agricultural industry (figure 1 shows beet pulp, potato pulp, post-slaughtering blood with bran, fish waste, brewers' grains, sawdust).

According to the Research and Development Centre of Fabryka Maszyn Rolniczych (Agricultural Machines Factory) RPFAMA in Rogoźno Wielkopolskie (presently "AGROMECH" - Rogoźno Wlkp.) the amount of the heat flowing from the waste gases exhaust pipe of SB 1.5 drum drier is estimated at approximately $1.6 \mathrm{mln} \mathrm{kJ}^{-1}$. Exploitation research conducted by Kalisiewicz (1965), Kulik (1982), Biłowicki (1984) show that the amount of waste heat of SB 1.5 drum drier is approximately $1.7 \mathrm{mln} \mathrm{kJ} \cdot \mathrm{h}^{-1}$.

The authors conducted exploitation research of drum driers, inter alia, of SB 1.5 - however, they were partial. Therefore, they recognized that the research carried out by IBERU team was more representative and complex (Kalisiewicz et al., 1965) and they applied it in this article. 


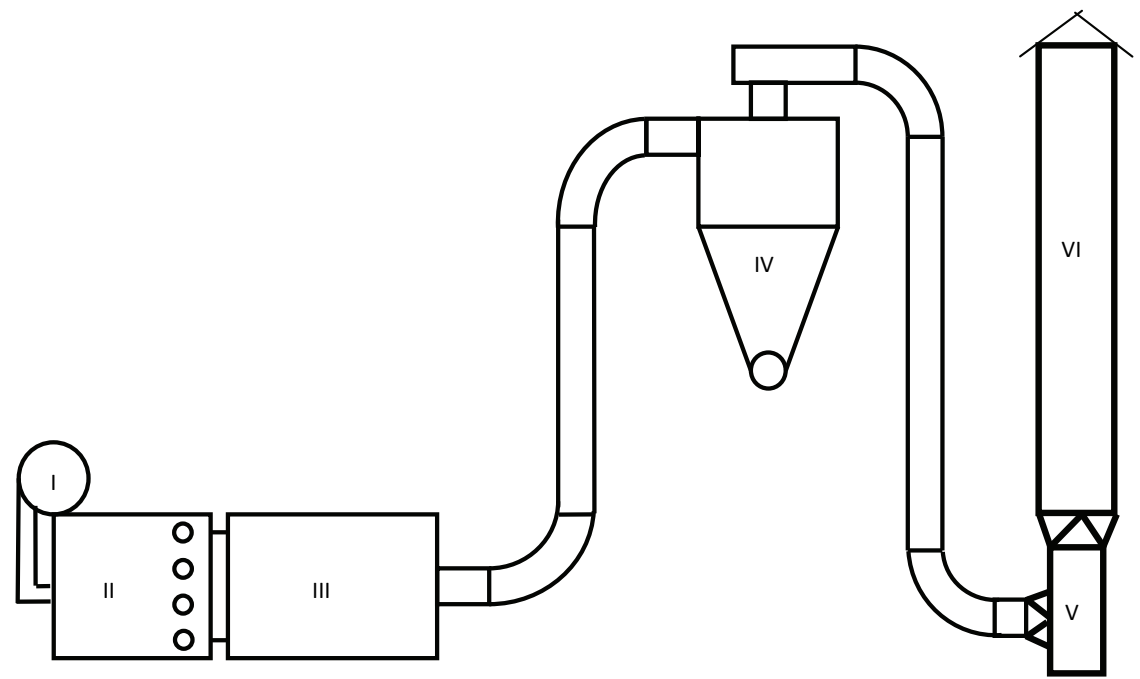

Fig. 1.Schematic representation of SB 1.5 drum drier with a stove for liquid fuel, I-furnace fan blower, II - furnace, III - drying drum, IV - main cyclone, $V$ - main fan, VI-waste gases pipe

Table 1 presents the selected data from 7-day exploitation measurements of SB 1.5 drum drier with a mazut furnace - during drying of green meadow fodder (Kalisiewicz et al., 1965).

Table 1.

Selected data from measurements on a drying facility

Average

\begin{tabular}{|c|c|c|c|c|c|c|c|c|}
\hline $\begin{array}{l}\text { Heat drifted with a drying } \\
\text { medium }\left(\mathrm{kJ} \cdot \mathrm{h}^{-1}\right)\end{array}$ & 1856170 & 1520970 & 1575440 & 1705330 & 1743040 & 1877120 & 1759800 & 1719700 \\
\hline $\begin{array}{l}\text { Temperature of a medium } \\
\text { at the outlet from a fan } \\
\left({ }^{\circ} \mathrm{C}\right)\end{array}$ & 99 & 93 & 94 & 99 & 96 & 99 & 102 & 97.5 \\
\hline $\begin{array}{l}\text { External temperature of } \\
\text { the wall of the waste gases } \\
\text { pipe }\left({ }^{\circ} \mathrm{C}\right)\end{array}$ & 78 & 75 & 76 & 79 & 74 & 79 & 82 & 78 \\
\hline Main fan output $\left(\mathrm{m}^{3} \mathrm{~h}^{-1}\right)$ & 27400 & 27690 & 25700 & 26580 & 26780 & 27900 & 25990 & 26863 \\
\hline $\begin{array}{l}\text { Relative humidity of air in } \\
\text { the vicinity of a drier }(\%)\end{array}$ & 58 & 55 & 65 & 58 & 58 & 66 & 60 & 60 \\
\hline $\begin{array}{l}\text { Relative moisture of the } \\
\text { surrounding }(\%)\end{array}$ & 85 & 65 & 90 & 70 & 75 & 85 & 67 & 77 \\
\hline $\begin{array}{l}\text { Surrounding air tempera- } \\
\text { ture }\left({ }^{\circ} \mathrm{C}\right)\end{array}$ & 17 & 27 & 18 & 17 & 17 & 16 & 17 & 18 \\
\hline $\begin{array}{l}\text { Temperature next to the } \\
\text { drier }\left({ }^{\circ} \mathrm{C}\right)\end{array}$ & 24 & 32 & 29 & 25 & 26 & 25 & 24 & 26.4 \\
\hline
\end{tabular}


Assessment of utilization...

\section{Concepts of using waste heat of drum driers}

Aiming at energy savings some companies which produce drum driers (Van der Broec'k, Promill, Atlas, Swiss Combi, Kunz) cooperating with the users or research centres developed numerous manners and devices for heat recovery from waste gases (Peroń and Zdrojewski, 1990; Strawiński, 1984; Siatka and Mieczyński, 1985).

They mainly consist in:

- partial recirculation of waste gases to the modified furnace,

- use of waste heat for blanching raw materials which facilitates mechanical squeezing of cell sap. This sap subsequently compacted in an evaporator is added to the squeezed fraction of raw material and transferred to the drier therewith,

- partial use of the waste heat energy for the drive of the absorption fridge. The authors do not present a detailed description of these methods due to the limits of the article. In relation to the solution, they enable reduction of a unit demand for heat from approximately $10 \%$ to approximately $30 \%$. Majority of the mentioned concepts have not been accepted by domestic users of drying facilities because of many reasons (high costs of adaptation of existing devices, change in the technology, disturbances in the pneumatic transport system of the drying factor etc.) Discussions between the authors and managers of the drying facilities, equipped with SB 1.5 driers (facilities in Blizanowice near Wrocław, Ciechów near Środa Śląska, Boguszyce near Oleśnica, Sępno Wielkopolskie voivodeship) show that they would be able to accept simple solutions which do not disturb the pneumatic transport system. (Peroń and Zdrojewski, 1992; 1987) presented a model research and the manner of using the heat conducted by the side surface of waste gases for drying agricultural grain raw materials. Figure 2 explains the concept. The suggested solution does not disturb the drying agent transport.

Figure 2. Concept of utilization of heat conducted through the waste gases exhaust pipe of $S B 1.5$ drum drier for drying grain 1 - waste gases exhaust pipe, 2 - internal screening cylinder, 3-grain, 4-external screening cylinder, 5-fan

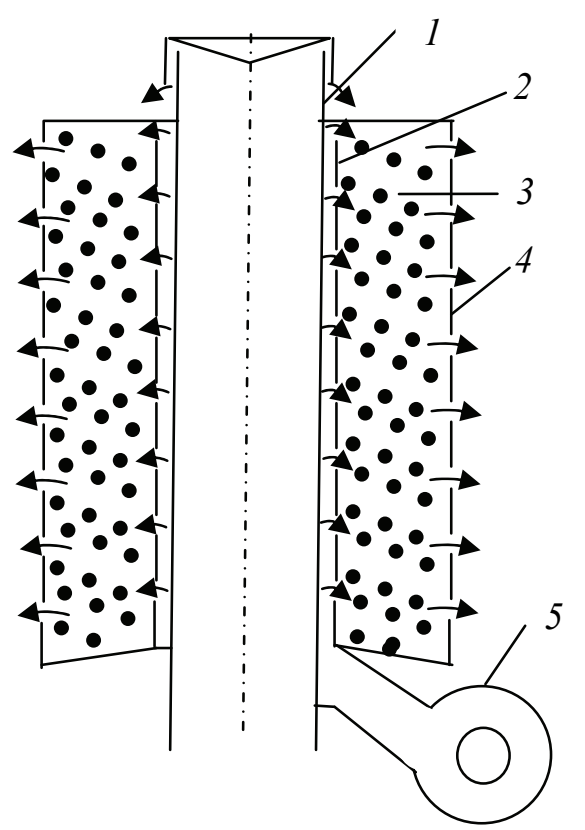




\section{The objective of the paper}

In this article the authors suggest a different, more universal concept of using the heat conducted by the waste gases exhaust pipe for drying purposes. The solution enables connection of the waste heat source with any drying chamber (silos, floor drier, etc.) filled with grain raw material (grain, wood chips) or non-refined raw material (straw, corn cobs etc.) Figure 3 presents a concept suggested by authors.

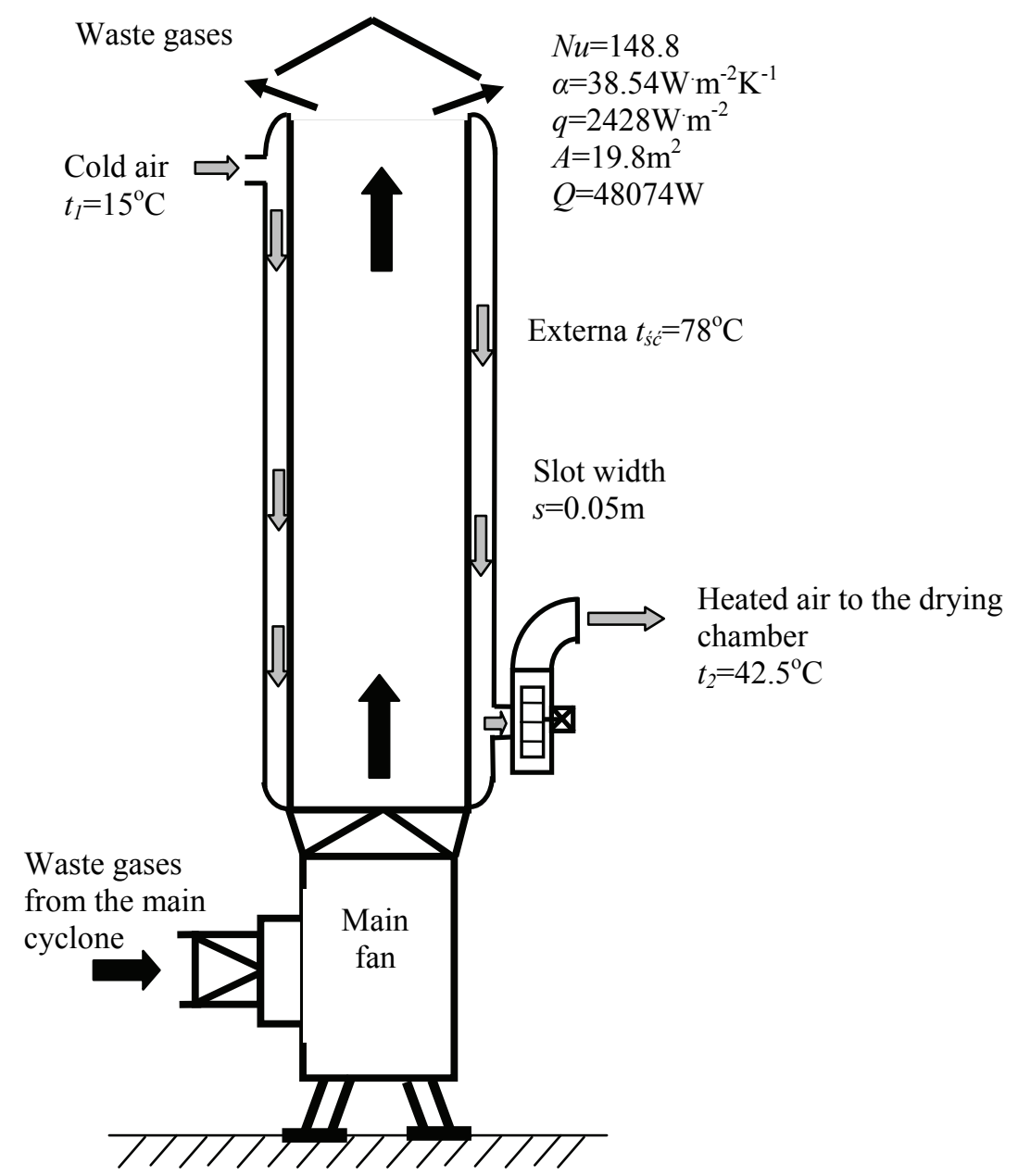

Figure 3. The concept of using heat conducted by the waste gases pipe for drying

According to table 1, average temperature of the external surface of waste gases pipe wall of the drum drier is $78^{\circ} \mathrm{C}$. Taking into consideration its external diameter which is approximately $0.9 \mathrm{~cm}$ and its height of approximately $9 \mathrm{~m}$, we have a heat source with the 
Assessment of utilization...

surface area of approximately $23 \mathrm{~m}^{2}$. The objective of the paper is to evaluate the utilization possibilities of such heat source for drying.

Having no information on the distribution of gas temperature along the waste gases exhaust pipe and on its side surface, the authors knew only the temperature of the external surface of the pipe at the half of its height, which gave a chance for an approximate evaluation of the heat source penetrating air therefrom. Taking into account that the heat flowing out with waste gases is at the average 10 times higher than the heat lost through cylindrical walls of apparatus laved by air (Gawrzyński and Glaser, 1998) the authors assumed that the average temperature of the external wall of the pipe will change slightly at the length.

\section{Assessment of the amount of heat which can be obtained from the external surface of the waste gases pipe}

The authors assumed that

- the height of the length of waste gases from which heat will be collected will be $\mathrm{h}=7 \mathrm{~m}$ with its area of $\mathrm{A}=19.8 \mathrm{~m}^{2}$ and the average temperature at the surface of the entire pipe, which was approximately $78^{\circ} \mathrm{C}$;

- the width of the slot between the internal and external pipe was $\mathrm{s}=50 \mathrm{~mm}$;

- the external pipe will be insulated with "afol" type insulation to reduce the heat losses;

- the exchanger will cooperate with SPA20 flat-bottom silos with the diameter of $\phi=3.05$ $\mathrm{m}$, the height of the cylindrical part $\mathrm{H}=3.65 \mathrm{~m}$ and the utility volume of $V=26.6 \mathrm{~m}^{3}$ filled with chips with a bulk density of $\rho_{m}=255 \mathrm{~kg} / \mathrm{m}^{3}$ and mass $M=6800 \mathrm{~kg}$;

- the flow speed of the drying agent through a layer of chips was assumed as $w_{s}=0.2 \mathrm{~m}^{-1}$ (Hunder, 2007), which means that the required volumetric expenditure of the fan cooperating with a silo is:

and the mass

$$
\dot{V}_{a}=\frac{\pi \cdot \phi}{4} \cdot w_{s}=\frac{\pi \cdot 3,05^{2}}{4} \cdot 0,2=1,461 \mathrm{~m}^{3} \cdot \mathrm{s}^{-1}=5260 \mathrm{~m}^{3} \cdot \mathrm{h}^{-1}
$$

$$
m_{a}=\dot{V}_{a} \cdot \rho=5260 \cdot 1,2=1,75 \mathrm{~kg} \cdot \mathrm{s}^{-1}
$$

at the air density of $\rho=1.2 \mathrm{kgm}^{-3}$

- the air flow speed in the ring conduit of the heat exchanger resulting from the fan expenditure:

$$
\mathrm{W}=\frac{\dot{\mathrm{V}}_{\mathrm{a}}}{\frac{\pi \mathrm{D}^{2}}{4} \frac{\pi \mathrm{d}^{2}}{4}}=\frac{1,461}{\frac{\pi \cdot 0,997^{2}}{4}-\frac{\pi \cdot 0,897^{2}}{4}}=9,82 \mathrm{~m} \cdot \mathrm{s}^{-1}
$$

- Reynolds' number (Serwiński, 1971):

where:

$$
\mathrm{Re}=\frac{\mathrm{w} \cdot \mathrm{d}_{\mathrm{Z}} \cdot \rho}{\eta}=\frac{\mathrm{w} \cdot(\mathrm{D}-\mathrm{d}) \cdot \rho}{\eta}=\frac{9,82 \cdot(0,997-0,897) \cdot 1,2}{18,14 \cdot 10^{-6}}=64995
$$

$\mathrm{d}_{\mathrm{z}}$ - hydraulic diameter,

D - internal diameter of the external pipe,

d - external diameter of the waste gases exhaust pipe. 
- thermal transmittance coefficient $\alpha$ from the internal pipe of the exchanger (external surface of the waste gases pipe) to air was calculated from McAdams equation (Troniewski et al., 2012):

it will be

$$
\mathrm{Nu}=0,021 \mathrm{Re}^{0,8}=0,021 \cdot 64995^{0,8}=148,8
$$

where:

$\lambda$ - coefficient of thermal transmittance through air $\left(\mathrm{W} \cdot\left(\mathrm{m}^{-1} \mathrm{~K}^{-1}\right)\right)$, thus the heat stream collected by air:

$$
\mathrm{q}=\alpha\left(\mathrm{t}_{\text {ś }}-\mathrm{t}_{1}\right)=38,54(78-15)=2428 \mathrm{~W} \cdot \mathrm{m}^{-2}
$$

and heat obtained from the entire area of the exchanger:

$$
\mathrm{Q}=\mathrm{q} \cdot \mathrm{A}=2428 \cdot 19,8=48074 \mathrm{~W}
$$

If $\mathrm{Q}$ heat is entirely (without losses) collected by air laving from outside the hot wall of waste gases exhaust pipe thus $\mathrm{Q}=\mathrm{m}_{\mathrm{a}} \cdot \mathrm{C}_{\mathrm{a}} \cdot \Delta \mathrm{t}_{\mathrm{w}}$ the change of air temperature at the outlet from the exchanger is:

where:

$$
\Delta \mathrm{t}_{\mathrm{w}}=\frac{\mathrm{Q}}{\mathrm{m}_{\mathrm{a}} \cdot \mathrm{C}_{\mathrm{a}}}=\frac{48078}{1,75 \cdot 1000}=42,5^{\circ} \mathrm{C}
$$

$\mathrm{C}_{\mathrm{a}} \quad$ - specific heat of $\operatorname{air}\left(\mathrm{J} \cdot\left(\mathrm{kg}^{-1} \cdot \mathrm{K}^{-1}\right)\right)$.

Assessment of the drying time of chips based on the i-x diagram

- Assuming the initial humidity of chips $\mathrm{w}_{1}=50 \%$ and the final $\mathrm{w}_{2}=20 \%$

Mass of dried chips

$$
\mathrm{S}=\mathrm{M} \frac{100-\mathrm{w}_{1}}{100-\mathrm{w}_{2}}=6800 \frac{100-50}{100-20}=4250 \mathrm{~kg}
$$

Thus the mass of water to be evaporated

$$
\mathrm{W}=6800-4250=2550 \mathrm{~kg} \mathrm{H}_{2} \mathrm{O}
$$

- the $\mathrm{i}$-x diagram shows that for air temperature at the inlet $\mathrm{t}_{1}=15^{\circ} \mathrm{C}$ and relative humidity $\phi_{1}=0.8$ the water content is $\mathrm{x}_{1}=8.2 \mathrm{~g} \mathrm{H}_{2} \mathrm{O} \mathrm{kg}^{-1}$ s.p. After heating to the temperature of $42.5^{\circ} \mathrm{C}$ its relative humidity dropped to $\phi_{2}=0.15$. According to the theoretical drying process, after going through the layer of material, each kilo of air contains $\mathrm{x}_{2}=17.5 \mathrm{~g}$ $\mathrm{H}_{2} \mathrm{O} \mathrm{kg}^{-1}$ s.p. Therefore, it may take $\Delta \mathrm{x}=17.5-8.2=9.3 \mathrm{~g} \mathrm{H}_{2} \mathrm{O}$. Knowing the mass of water to be evaporated $\mathrm{W}=2550 \mathrm{~kg} \mathrm{H}_{2} \mathrm{O}$ and $\Delta \mathrm{x}=9.3 \mathrm{~g} \mathrm{H}_{2} \mathrm{O} \mathrm{kg}^{-1}$ s.p theoretical mass of air required for drying is

$$
\mathrm{m}_{\mathrm{p}}=\frac{2550000}{9,3}=274193,5 \mathrm{~kg}
$$


Assessment of utilization...

and time

$$
\tau=\frac{\mathrm{m}_{\mathrm{p}}}{\mathrm{m}_{\mathrm{a}}}=\frac{274193,5}{6312}=43,5 \text { godzin }
$$

\section{Evaluation of energy profits}

According to calculations, $48 \mathrm{~kJ}$ of heat may be obtained within one second from the entire surface and $172,800 \mathrm{~kJ}$ of heat within one hour. It is an equivalent of approximately 4.12 kilo of heating oil (it was assumed that the calorific value of diesel oil was 42,000 $\mathrm{kJ} \mathrm{kg}^{-1}$ ). At the drying time of $\tau=43.5$ hours savings of heating oil (indispensable for heating air) will be approximately 416 kilo. Assuming that SB 1.5 drum drier works ca. 1000 hours a year (100 days x 10 hours) an energy profit from using the authors' concept - expressed in heating oil may achieve 4000 kilo year $^{-1}$.

Literature (Rybak, 2006) proves that chips in relation to humidity have a calorific value of 6,000 to $16,000 \mathrm{~kJ} \mathrm{~kg}^{-1}$. Assuming that drying from $50 \%$ to $20 \%$ will cause the increase of the calorific value from 6,000 to $15,000 \mathrm{~kJ} \mathrm{~kg}^{-1}$, we may obtain the energy increase with reference to the entire mass of raw material due to drying in the amount of:

where:

$$
\Delta E=\Delta w_{u} \cdot W=(15000-9000) \cdot 2550=22950000 \mathrm{~kJ}
$$

$\Delta \mathrm{w}_{\mathrm{u}}$ - change of the calorific value.

The value of $22950000 \mathrm{~kJ}$ constitutes an equivalent of approx. 546 kilo of heating oil.

The evaluated energy profits should be reduced by energy indispensable for driving the fan which sucks air by the heat exchanger. Assuming previously evaluated fan expenditure as $\dot{V}_{\mathrm{a}}=5.260 \mathrm{~m}^{3} \mathrm{~h}^{-1}=1.461 \mathrm{~m}^{3} \mathrm{~s}^{-1}$, elasticity $\Delta \mathrm{P}=1,000 \mathrm{~Pa}$, fan performance $\eta_{w}=0.7$ and performance of the fan engine $\eta_{s}=0.85$ - electric power collected from the network may be evaluated as approx. $2.5 \mathrm{~kW}$ which constitutes approx. $5 \%$ of thermal power obtained from the exchanger. Losses resulting from the real process of drying are at the average of $10 \%$ $20 \%$ in comparison to the theoretical drying process in relation to the conditions of the process.

\section{Conclusion}

The suggested solution does not disturb the pneumatic transport system of SB 1.5 drier and constitutes the source of "clean" heat, without fumes, which may be used both for drying consumption or sowing grain and other raw materials (e.g. chips, straw, pomace).

According to the authors the concept enables, the use of exhaust heat of SB 1.5 drier within $8-10 \%$. This solution creates a possibility of connecting the heat source with driers with an immovable bed of raw material (silo, floor drier, etc.). In case of using an additional heat source for drying, approximately 6,800 kilo of moist wood chips may be dried. In SPA 20 silo from moisture $\mathrm{w}_{1}=50 \%$ to $\mathrm{w}_{2}=20 \%$ - it may be expected that the drying time will be ca. 100 hours. According to calculations within one hour from the entire surface of the exchanger one may obtain approx. $113,000 \mathrm{~kJ}$ of heat, which constitutes an equivalent of approximately 4 kilo of heating oil. 
Assuming that SB 1.5 drum drier works ca. 1000 hours, the expected energy profit resulting from the applied solutions expressed in the heating oil may be ca. 4000 kiloyear $^{-1}$. The estimated electric power indispensable for the drive of the fan which sucks air through the heat exchanger constitutes ca. $5 \%$ of the thermal power obtained from the exchanger.

\section{References}

Biłowicki, J. (1984). Eksploatacyjne badania porównawcze różnych typów suszarń do zielonek. Zeszyty Problemowe Postępu Nauk Rolniczych, 282, 249-257.

Gawrzyński, Z., Glaser, R. (1998). Materiały do wykładów i ćwiczeń z maszynoznawstwa i aparatury przemysłu spożywczego i chemicznego. Wydawnictwo Akademia Ekonomiczna we Wrocławiu. ISBN 83-7011-5011-X

Hunder, M. (2007). Analiza procesu suszenia i przechowywania zrębków drzewnych $w$ aspekcie energetycznym, kosztowym i mikrobiologicznym. Rozprawa doktorska, IBMER Warszawa.

Kalisiewicz, A. (1965). Badania prototypu suszarki bębnowej SB 1,5 z piecem na paliwo ciekte. Sprawozdanie IBMER XXII.

Kulik, T. (1982). Metoda analizy wpływu parametrów procesu suszenia na szybkość suszenia pasz w suszarkach bębnowych. Mechanizacja Rolnictwa, 2, 16-19.

Peroń, S., Zdrojewski, Z. (1990). Sposoby wykorzystania ciepła gazów odlotowych rolniczych suszarek bębnowych. Maszyny i ciagniki rolnicze i leśne, 12, 15-18.

Peroń, S., Zdrojewski, Z. (1992). Konwekcyjna wymiana ciepła między ścianą rury gazów odlotowych suszarki bębnowej SB 1,5 a otaczającym ją „płaszczem ziarna”. Zeszyty Problemowe Postępu Nauk Rolniczych, 402, 17-29.

Peroń, S., Zdrojewski, Z. (1987). Wstępne badania nad wykorzystaniem ciepła przewodzonego przez pobocznicę „komina” suszarki bębnowej do suszenia ziarna. Zeszyty Naukowe Politechniki Łódzkiej, Inżynieria Chemiczna i Procesowa, 14, 218-224.

Rybak, W. (2006). Spalanie i współspalanie biopaliw stałych. Oficyna Wydawnicza Politechnika Wrocławskiej, Wroclaw, 59.

Serwiński, M. (1971). Zasady inżynierii chemicznej. WNT Warszawa, 80.

Siatka, J., Mieczyński, M. (1985). Skojarzone systemy ziębno-grzejne, wykorzystanie ciepła odpadowego w suszarni. Raport I-20/SPR nr 36/79. Politechnika Wrocławska.

Strawiński, A. (1984). Możliwości odzyskiwania ciepła oparów wydalanych z suszarki. Materiały V Sympozjum Suszarnictwa cz. 3, Wrocław, 384-393.

Troniewski, L., Czernek, R. (2012). Dane do obliczeń procesowych. Oficyna Wydawnicza Politechniki Opolskiej. Rozdział IV, 178-180. 
Assessment of utilization...

\section{OSZACOWANIE MOŻLIWOŚĆI WYKORZYSTANIA CIEPLA PRZEWODZONEGO PRZEZ RURE GAZÓW ODLOTOWYCH SUSZARKI BĘBNOWEJ SB 1,5 DO SUSZENIA ZRĘBKÓW DREWNA}

Streszczenie. W oparciu o badania eksploatacyjne autorzy dokonali oceny możliwości wykorzystania ciepła przewodzonego przez pobocznicę rury gazów odlotowych suszarki bębnowej SB 1,5 do suszenia zrębków drewna. Jak wynika $\mathrm{z}$ szacunkowych obliczeń $\mathrm{w}$ ciągu godziny $\mathrm{z}$ zewnętrznej powierzchni rury gazów odlotowych o wysokości $7 \mathrm{~m}$ i temperaturze ok. $78^{\circ} \mathrm{C}$ można uzyskać ok. 173 tys. $\mathrm{kJ}$ ciepła, co stanowi ekwiwalent ok. $4 \mathrm{~kg}$ oleju opalowego. W przypadku wykorzystania wyżej wymienionego źródła ciepła do suszenia zrębków drewna w silosie SPA 20 o pojemności $6800 \mathrm{~kg}$ od wilgotności $50 \%$ do 20\% można oczekiwać, że czas suszenia wyniesie ok 100 godzin.

Słowa kluczowe: ciepło odlotowe, suszarka bębnowa, zrębki drewna, suszenie 